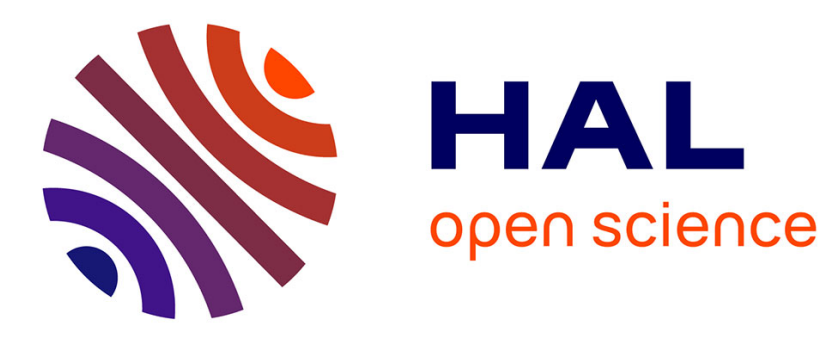

\title{
Wastewaters Reuse for Energy Crops Cultivation
} Jorge Costa, Bruno Barbosa, Ana Luisa Fernando

\section{To cite this version:}

Jorge Costa, Bruno Barbosa, Ana Luisa Fernando. Wastewaters Reuse for Energy Crops Cultivation. 7th Doctoral Conference on Computing, Electrical and Industrial Systems (DoCEIS), Apr 2016, Costa de Caparica, Portugal. pp.507-514, 10.1007/978-3-319-31165-4_47 . hal-01438277

\section{HAL Id: hal-01438277 \\ https://hal.inria.fr/hal-01438277}

Submitted on 17 Jan 2017

HAL is a multi-disciplinary open access archive for the deposit and dissemination of scientific research documents, whether they are published or not. The documents may come from teaching and research institutions in France or abroad, or from public or private research centers.
L'archive ouverte pluridisciplinaire HAL, est destinée au dépôt et à la diffusion de documents scientifiques de niveau recherche, publiés ou non, émanant des établissements d'enseignement et de recherche français ou étrangers, des laboratoires publics ou privés. 


\title{
Wastewaters Reuse for Energy Crops Cultivation
}

\author{
Jorge Costa ${ }^{1}$, Bruno Barbosa ${ }^{1,2}$ and Ana Luisa Fernando ${ }^{1}$ \\ 1 MEtRiCS, Departamento de Ciências e Tecnologia da Biomassa, Faculdade de Ciências e \\ Tecnologia, FCT, Universidade Nova de Lisboa, Campus de Caparica, 2829-516 Caparica, \\ Portugal,jrgecosta@gmail.com; ala@fct.unl.pt \\ 2 Universidade Federal do Oeste da Bahia, Barreiras, Brazil, barbosabruno5@gmail.com
}

\begin{abstract}
This study evaluated wastewaters reuse in the production of perennial crops Arundo donax and Miscanthus x giganteus. The trials were conducted in pots under controlled conditions, with different water regimes $(950,475$ and $238 \mathrm{~mm})$ in two growing cycles. The results indicated that irrigation with wastewaters did not affect biomass productivity but the amount of irrigation did. Yet, biomass obtained from pots irrigated with wastewaters presented higher levels of ash and nitrogen content than biomass from control pots. The soil-plant system retained over $90 \%$ of pollutant load resulting in wastewater depuration. Furthermore, the produced biomass can be economically valorized for energy or biomaterials, once irrigation with wastewater did not influence the contents in fiber and the calorific value. Still, the higher ash and nitrogen contents in the biomass can be detrimental especially when biomass is for combustion purposes.
\end{abstract}

Keywords: Arundo donax; Miscanthus x giganteus; energy crops; bioenergy; phytoremediation; wastewaters; sustainability.

\section{Introduction}

Most of the countries are too dependent on fossil fuels to meet their energy needs. The production of energy crops has been presented as a very promising alternative to partially replace the fossil fuels. Among the various species (preferably non-food) which can be grown to generate energy, Arundo donax L. (giant reed) and Miscanthus $\mathrm{x}$ giganteus Greef et Deu are presented as one of the most promising because of its high productivity, resistance to low water regimes, characteristic of the Mediterranean countries during summer, and pests $[1,2]$. Giant reed is a woody rhizomatous grass that was spread throughout Asia, Southern Europe, North Africa and the Middle East as an agent to control erosion in drainage channels [2, 3]. Miscanthus is a woody rhizomatous grass originated in South-East Asia and was initially imported to Europe as an ornamental plant. It is a perennial plant, related to sugarcane, with an estimated productive lifetime of at least 10-15 years, and both the stems and leaves of the crop can be harvested annually [2, 4]. Both crops have the ability to combat desertification and prevent soil erosion, thanks to its high efficiencies in the use of resources and also to its robust root system, high soil cover density and the fact that the stems keep alive during the winter $[3,5,6]$. Beyond the potential for use as energy crops, perennial 
grasses are associated with minimization of nutrient leaching as well as with the restoration of soil properties (fertility, structure, organic matter) due to the extensive radicular system [5-8]. Therefore it has been argued that these grasses can also be used to remove contaminants, such as nitrates or heavy metals, from soil and from wastewaters [7-12].

The irrigation of plants with treated wastewaters for contaminant removal is not new. This approach was developed as a final treatment stage in order to minimize the wastewater nutrient loads prior to its disposal in the environment. Because agriculture is a major consumer of water worldwide the same technique is also used to irrigate drought tolerant crops that are very efficient in the removal of nutrients and pollutants present in treated wastewaters. This can promote the creation of crop rotation systems more resilient, adding economic value and social benefits to water-scarce regions like the Mediterranean [7]. The use of wastewaters for energy crops irrigation, may allow not only counteracting the shortage or the precipitation seasonality but also to reduce the need of fertilizers, combining environmental and economic advantages. However, the presence of substances in wastewater, such as nitrates and heavy metals, may present environmental risks, besides representing a source of nutrients/toxics to the biomass. On this basis, this study was design to provide the answers to the following questions:

- Does irrigation with wastewaters affect the yields of $A$. donax and Miscanthus, in the Mediterranean region?

- Does irrigation with wastewaters affect the quality of the biomass as feedstock in energy and bioproducts uses?

- Does the amount of irrigation water added affect the yields and quality of biomass?

- Are these perennial grasses able to remediate the pollution load of wastewaters?

Some studies, but not many, have already evaluated the effect of giant reed and Miscanthus spp., irrigated with wastewaters [7]. However, most of them cover only the phytoremediation ability of the plants to the pollution load or the effects on yields, when no water stress is inflicted. Therefore, this study intends to provide more information on the adaptation of giant reed and Miscanthus spp. to the hydraulic loading. This will provide insights on the effects of the wastewater rate application on the yields and quality of biomass.

\section{Relationship to Cyber-Physical Systems}

The agricultural systems that generate food, feed, fiber, and fuels need to be more efficient and sustainable (economically, environmentally and socially). In order to accelerate this process, precision agriculture architecture based on cyber-physical systems (CPS) design technology is mandatory. CPS will help to increase efficiency throughout the value chain, improving our environmental footprint, and creating opportunities in the rural areas. For this, the scientific and technical challenges relay on the development of methods, tools, hardware and software components that can 
address this issue. Those need to be based upon transdisciplinary approaches, including the validation of the principles via pilot tests and field tests.

A precision agriculture architecture, that can provide autonomous irrigation management capabilities, based on CPS design technology, includes several layers: the physical layer, the network layer, the decision layer and the application layer.

The physical layer corresponds to the information acquisition process. Use of wireless sensors in field can monitor the moisture content of the soil in a continuous base, relaying the processed information to a central node. In the proposed architecture the information obtained from the wireless sensors will be transmitted by a tool that collects data from the field and provide the range of information required to the network nodes for the decision layer. In this decision layer, decisions will be obtained using artificial intelligence techniques. This system will create, store, analyse and process spatial information distributed through a computerized process regarding soil type, moisture content and correlate them with a certain plot of field. The application layer will provide solutions to incoming problems based on information processed and stored locally but also from knowledge bases. When the information processed indicates that the soil moisture content is below a defined value, the storage tanks with wastewaters can start pumping the water to the fields.

Another device installed in the storage tanks also monitors the existing volume of wastewaters and predicts the wastewaters incoming per hour based on the wastewater treatment plant design and process. By means of an intelligence mechanism (a developed software), the wastewater in the fields will be distributed according to both indicators, soil moisture and wastewater availability. The control mechanism will stop irrigation when a) the soil moisture returns to the optimal level for perennial grasses production, and/or b) the volume of wastewater is limited. Information on the growing cycle of the plants (needs of water per day, along the vegetation period) has to be uploaded in the system, in order to adjust the water distribution with minimal stresses for the plant. The main purpose of such an integrated system is to provide a solution for multispectral monitoring of perennial grasses irrigation with wastewaters based on mechatronic systems, in order to improve precision agricultural management. This work intends to provide new data that can be treated and uploaded in such a system, helping to design an optimized response.

\section{Materials and Methods}

The trials were established in April 2012 in pots. Both species, Arundo donax and M. $\mathrm{x}$ giganteus were tested. In each pot $\left(0.06154 \mathrm{~m}^{2}, 12 \mathrm{~kg}\right.$ of soil) 2 rhyzomes were established per pot and replicates were also established. After the establishment of the rhyzomes, pots were fertilized: $3 \mathrm{~g} \mathrm{~N} / \mathrm{m}^{2}$ (urea, $46 \% \mathrm{~N}$ ); $3 \mathrm{~g} \mathrm{~N} / \mathrm{m}^{2}$ (nitrolusal, mixture of $\mathrm{NH}_{4} \mathrm{NO}_{3}+\mathrm{CaCO}_{3}, 27 \% \mathrm{~N}$ ); $17 \mathrm{~g} \mathrm{~K}_{2} \mathrm{O} / \mathrm{m}^{2}$ (potassium sulphate, $51 \% \mathrm{~K}_{2} \mathrm{O}$ ); $23 \mathrm{~g}$ $\mathrm{P}_{2} \mathrm{O}_{5} / \mathrm{m}^{2}$ (superphosphate, $18 \% \mathrm{P}_{2} \mathrm{O}_{5}$ ). Three different wastewater irrigating regimes were applied in the pots: $950 \mathrm{~mm}, 475 \mathrm{~mm}$ and $238 \mathrm{~mm}$. A piggery effluent was tested. In all experiments, control pots were also tested with the same water regimes but wastewater was replaced by tap water. 
At the end of each growing season (January 2013 and January 2014), the plants were harvested and the productivity and biomass quality were monitored. To determinate the productivity of the biomass, the total aerial dry weight was determined at each harvest. The radicular productivity was determined also, but only on the 2nd harvest date (January 2014). The quality of the biomass harvested was analysed taking in consideration the following parameters: ash and nitrogen content, as also, fiber content and the calorific value. The analyses were performed according to the following procedures: a) ash content: by calcination at $550^{\circ} \mathrm{C}$ for two hours, in a muffler furnace; b) nitrogen content: by the Kjeldahl method, after digestion of the sample; c) Hemicellulose $(\mathrm{H})$, cellulose $(\mathrm{C})$ and lignin $(\mathrm{L})$ were determined by the van Soest method [13]; d) calorific value, by an adiabatic calorimeter. Tap water and wastewater were analyzed according to the Standard Methods for the examination of water and wastewater [14].

The statistical interpretation of the results was performed using analysis of variance (one-way ANOVA) (Statistica 6.0 program). LSD Fisher's test was applied to separate means when ANOVA revealed significant differences. The results were presented as the mean \pm standard deviation.

\section{Results and Discussion}

Table 1 shows the physical-chemical characterization of the tap water (used in the control pots) and wastewater.

Table 1. Physicochemical characterization of tap water and piggery wastewater used in the trials

\begin{tabular}{cccc}
\hline Parameter & $\begin{array}{c}\text { Expression of } \\
\text { results }\end{array}$ & Wastewater & Tap water \\
\hline $\mathrm{pH}$ & Sorensen scale & $6.9 \pm 0.1$ & $6.1 \pm 0.2$ \\
Electrical Conductivity & $\mathrm{mS} \mathrm{cm}^{-1}$ & $0.53 \pm 0.04$ & $0.42 \pm 0.02$ \\
Oxidability & $\mathrm{mgO}_{2} \mathrm{dm}^{-3}$ & $12 \pm 5$ & $0.23 \pm 0.08$ \\
Ammonia & $\mathrm{mg} \mathrm{N} \mathrm{dm}^{-3}$ & {$[3.3-27.7]$} & $<0.14$ \\
Chlorides & $\mathrm{mg} \mathrm{Cl}^{-}$dm$^{-3}$ & $99 \pm 6$ & $81 \pm 2$ \\
Nitrates & $\mathrm{mg} \mathrm{N} \mathrm{dm}^{-3}$ & $5.4 \pm 3.5$ & $5.5 \pm 0.08$ \\
Phosphates & $\mathrm{mg} \mathrm{P} \mathrm{dm}^{-3}$ & $0.62 \pm 0.25$ & $0.042 \pm 0.002$ \\
BOD5 & $\mathrm{mg} \mathrm{O}_{2} \mathrm{dm}^{-3}$ & $6 \pm 2$ & - \\
\hline
\end{tabular}

Table 1 show that the wastewater has higher organic matter content than tap water, as also, ammonia and chlorides. But, regarding nitrates and mineral composition, both waters presented similar results.

Fig. 1 shows the yields after two growing cycles and allows highlight that the higher the water regime applied, the greater the yield. Similar findings were already presented and discussed in the literature [1, 15]. This indicates that these grasses prefer high water availability. Evaluating the plant as a whole, it is found that generally irrigation with wastewaters did not produce (in the tested water regimes) 
significant changes in biomass yield. Similar results were verified in literature by other authors [9], indicating that those grasses are tolerant to these type of wastewaters with this degree of salinity. Results obtained confirmed the results verified in the first growing season, but where the yields were lower [10, 12]. These plants give priority, in the first years, to the establishment of the root-rhizome system, compared to the other vegetative structures, a feature that had already been indicated by Angelini et al. [16]. $M$. x giganteus was significantly more productive than $A$. donax, a feature already observed by other authors [17]. Results also show that $M$. x giganteus accumulates $130 \mathrm{~g} \mathrm{~m}^{-2}$ biomass per additional $100 \mathrm{~mm}$ of irrigation water, and $A$. donax accumulates $80 \mathrm{~g} \mathrm{~m}^{-2}$ biomass per additional $100 \mathrm{~mm}$ of irrigation water, in the range studied [238-950mm].

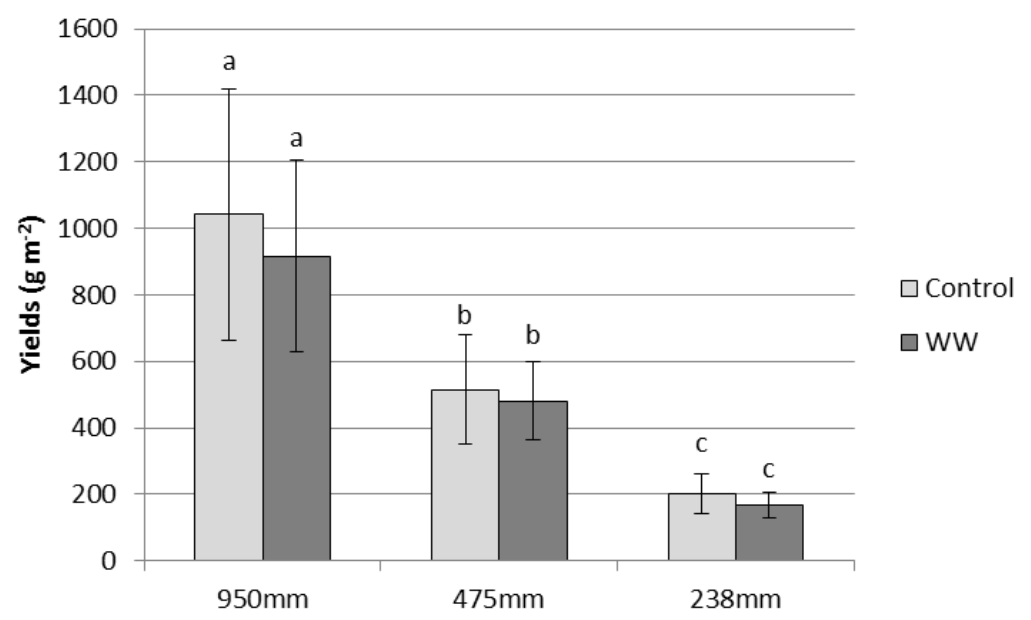

Fig. 1. Perennial grasses yields at different irrigation regimes at the end of the second growing cycle. Different lower-case letters indicate statistical significance $(p<0.05)$ between irrigation regimes. WW-wastewater.

Regarding the quality of the biomass for energy purposes, stems (the fraction of interest for combustion purposes and others) were the part of the plant that presented the lowest ash content, with average ash levels of $4.6 \%$, in the case of $A$. donax and $2.5 \%$, in the case of $M . \mathrm{x}$ giganteus. Due to the lower ash content, $M . \mathrm{x}$ giganteus present a better quality for energy purposes than $A$. donax. Both species presented a trend for a higher ash content when irrigated with wastewater. As wastewater is richer in salts (showed by the higher electrical conductivity, Table 1), those accumulate in higher amounts in the biomass, during the growing season. A trend for increasing ash content was observed, in the plants, by lowering the water regime. Nassi o Di Nasso et al. [18] highlighted the inverse variation between productivity and ash content, a fact that explains the observed trend.

Stems were the fraction of the plant with lower nitrogen content either. A. donax showed average nitrogen content of $0.5 \%$ (dry basis) and $M$. x giganteus average nitrogen content of $0.11 \%$ (dry basis). The lower nitrogen content presented by $M$. x giganteus stems corroborates the fact that this grass presents a better quality for 
energy purposes than $A$. donax. Both species showed a tendency to higher nitrogen accumulation in the biomass with wastewater irrigation. This increment reflects the wastewater richness in nitrogen (especially ammonia, Table 1). For both species, lower nitrogen content in the biomass was obtained with the application of higher water regimes, suggesting the dilution effect observed also by Nassi o Di Nasso et al. [18], with the increasing yields.

Furthermore, the produced biomass can be economically valorized for energy or biomaterials production, once irrigation with wastewater did not influence the contents in hemicellulose, cellulose and lignin, and the calorific value. A. donax biomass showed average fiber content of $87 \%(\mathrm{H}=32 \%, \mathrm{C}=31 \%$ and $\mathrm{L}=24 \%)$ and a calorific value of $17.2 \mathrm{MJ} / \mathrm{kg}$. M. x giganteus biomass showed average fiber content of $91 \%$ (from this, $\mathrm{H}=21 \%, \mathrm{C}=38 \%$ and $\mathrm{L}=23 \%$ ) and a calorific value of $17.4 \mathrm{MJ} / \mathrm{kg}$

The soil-plant system retained over $90 \%$ of pollutant load resulting in wastewater depuration.

\section{Conclusions}

Results of yields obtained for both energy crops (giant reed and Miscanthus) reflect that these perennial grasses can tolerate this sort of wastewaters with this degree of salinity. The soil-plant system retained over $90 \%$ of the pollutant load resulting in wastewater depuration. The use of wastewaters to irrigate these grasses presents environmental advantages in terms of carbon sequestration and water and mineral resources depletion. Carbon sequestration by roots and rhizomes may improve also soil structure, soil organic matter content and soil aeration, factors that contribute to reduce soil erosion and to control desertification. If leaves are left in the soil, at harvest, this fraction can also contribute to carbon sequestration. Irrigation with wastewaters enables the recycle of nutrients $(\mathrm{N}, \mathrm{P}$ and $\mathrm{K})$ and minimizes the need for fertilizer application in soils. Consequently, the NPK production or extraction from mineral ore reserves is reduced, with economic and energetic revenues, along with mineral and fossil resources savings. Wastewater reuse represents also an approach to economize freshwater and may contribute to aquifer refilling. Furthermore, the produced biomass can be economically valorized for energy or biomaterials production, once irrigation with wastewater did not influence the contents in fiber and the calorific value. Still, wastewater irrigation induces in the biomass a higher accumulation of ash and nitrogen, which can be detrimental when processing biomass, especially for combustion.

Acknowledgments. This work was supported by the European Union (Project Optimization of perennial grasses for biomass production (OPTIMA), Grant Agreement No: 289642, Collaborative project, FP7-KBBE-2011.3.1-02. 


\section{References}

1. Cosentino S.L., Scordia D., Sanzone E., Testa G., Copani V.: Response of giant reed (Arundo donax L.) to nitrogen fertilization and soil water availability in semi-arid Mediterranean environment, European Journal of Agronomy 60, 22-32 (2014).

2. El Bassam, N.: Handbook of Bioenergy Crops. A complete reference to species, development and applications. Earthscan Ltd, London, UK (2010).

3. Fernando, A.L., Barbosa, B., Costa, J., Papazoglou, E.G.: Giant reed (Arundo donax L.): a multipurpose crop bridging phytoremediation with sustainable bio-economy, In: Prasad, M.N.V. (ed.) Bioremediation and Bioeconomy, pp. 77-95. Elsevier Inc., UK (2016).

4. Fernando, A.L., Oliveira, J.F.S.: Caracterização do potencial da planta Miscanthus x giganteus em Portugal para fins energéticos e industriais. In: Manuel Robalo (ed.) Biologia Vegetal e Agro-Industrial, 2, pp. 195-204. Edições Sílabo, Lisboa (2005).

5. Oliveira, J.S, Duarte, M.P., Christian, D.G., Eppel-Hotz, A., Fernando, A.L.: Environmental aspects of Miscanthus production. In: Jones, M.B and Walsh, M. (eds.) Miscanthus for energy and fibre, pp 172-178. James \& James (Science Publishers) Ltd, London, UK (2001).

6. Fernando, A.L., Duarte, M.P., Almeida, J., Boléo, S., Mendes, B.: Environmental impact assessment of energy crops cultivation in Europe, Biofuels, Bioproducts and Biorefining 4, 594-604 (2010).

7. Barbosa, B., Costa, J., Fernando, A.L., Papazoglou E.G. Wastewater reuse for fiber crops cultivation as a strategy to mitigate desertification, Industrial Crops and Products 68, 17-23, (2015).

8. Barbosa, B., Costa, J., Boléo, S., Duarte, M.P., Fernando, A.L. Phytoremediation of inorganic compounds. In: Ribeiro, A.B., Mateus, E.P., Couto, N. (eds) Electrokinetics Across Disciplines and Continents - New Strategies for Sustainable Development, pp. 373400. Springer International Publishing, Switzerland (2016).

9. Mavrogianopoulos, G., Vogli, V., Kyritsis, S. Use of wastewaters as a nutrient solution in a closed gravel hydroponic cultures of giant reed (Arundo donax), Bioresource Technology, 82 (2002) 103-107.

10.Costa, J., Fernando, A.L., Coutinho, M., Barbosa, B., Sidella, S., Boléo, S., Bandarra, V., Duarte, M.P., Mendes, B. Growth, Productivity and Biomass Quality of Arundo Irrigated with $\mathrm{Zn}$ and $\mathrm{Cu}$ Contaminated Wastewaters, in: Eldrup A., Baxter D., Grassi A., Helm P. (eds.) Proceedings of the 21st European Biomass Conference and Exhibition, Setting the course for a Biobased Economy, pp. 308 - 310, ETA-Renewable Energies and WIPRenewable Energies (2013).

11. Lino, J., Fernando, A.L., Barbosa, B., Boléo, S., Costa, J., Duarte, M.P., Mendes, B. Phytoremediation of Cd and Ni Contaminated Wastewaters by Miscanthus. In: Hoffmann C, Baxter D, Maniatis K, Grassi A, Helm P (eds.) Proceedings of the 22th European Biomass Conference and Exhibition, Setting the course for a Biobased Economy, ETA-Renewable Energies, pp 303 - 307 (2014).

12. Bandarra V, Fernando AL, Boléo S, Barbosa B, Costa J, Sidella S, Duarte MP, Mendes B.: Growth, Productivity and Biomass Quality of Three Miscanthus Genotypes Irrigated with $\mathrm{Zn}$ and $\mathrm{Cu}$ Contaminated Wastewaters. In: Eldrup A, Baxter D, Grassi A, Helm P (eds.), Proceedings of the 21th European Biomass Conference and Exhibition, Setting the course for a Biobased Economy, ETA-Renewable Energies and WIP-Renewable Energies, pp 147 150 (2013).

13.Van Soest P.J., Robertson J.B., Lewis B.A.: Methods for Dietary Fiber, Neutral Detergent Fiber, and Nonstarch Polysaccharides in Relation to Animal Nutrition, Journal of Dairy Science 74, 3583-3597(1991).

14. APHA, AWWA e WPCF: Standard Methods for the examination of water and wastewater. 16th Ed. American Public Health Association, American Water Works Association e Water Pollution Control Federation, Washington D.C., USA, (1985). 
508 J. Costa et al.

15.Cosentino, S. L., Patanè, C., Sanzone, E., Copani, V. and Foti, S:. 'Effects of soil water content and nitrogen supply on the productivity of Miscanthus $\times$ giganteus Greef et Deu. in a Mediterranean environment'. Industrial Crops and Products, 25, 75-88 (2007).

16. Angelini L.G., Ceccarini L., Di Nasso N.N., Bonari E.: Comparison of Arundo donax L. and Miscanthus x giganteus in a long-term field experiment in Central Italy: Analysis of productive characteristics and energy balance. Biomass and Bioenergy, 33, 635-643 (2009).

17. Barbosa B, Boléo S, Sidella S, Costa J, Duarte MP, Mendes B, Cosentino SL, Fernando AL.: Phytoremediation of Heavy Metal-Contaminated Soils Using the Perennial Energy Crops Miscanthus spp. and Arundo donax L., BioEnergy Research, 8, 1500-1511 (2015).

18.Nassi o Di Nasso N., Angelini L. G., Bonan E.: Influence of fertilisation and harvest time on fuel quality of giant reed (Arundo donax L.) in central Italy, European Journal of Agronomy, 32, 219-227 (2010). 